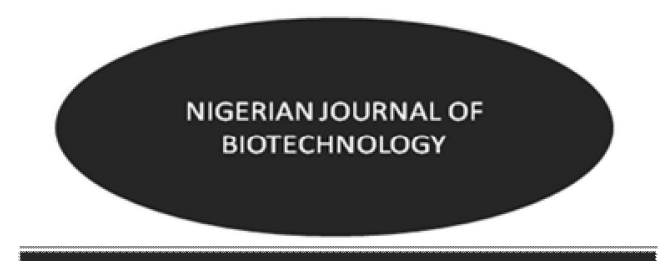

\title{
Effects of Fermentation and Extrusion on the Proximate Composition of Corn-Groundnut Flour Blends.
}

\author{
Olatubi, O. K. and Ojokoh, A. O. \\ Department of Microbiology, Federal University of Technology, P.M.B. 704, Akure, Nigeria.
}

\begin{abstract}
Effect of fermentation and extrusion on the proximate composition of com-groundnut flour blends were investigated. The corn-groundnut flour blends were prepared to six combinations (100:0, 90;10, 80:20, 70:30, 60:40 and 50:50) during extrusion. During fermentation of the extrudates, a total number of 14 micro-organisms were isolated; these comprises of eight (8) bacteria, five (5) moulds and one (1) yeast. They include Bacillus subtilis, Bacillus licheniformis, Leuconostoc mesenteroides, Klebsiella aerogenes, Staphylococcus aureus, Lactobacillus plantarum, Lactobacillus brevis, Micrococcus luteus, Rhizopus nigricans, Aspergillus niger, Aspergillus saprophyticus, Saccharomyces cerevisiae, Penicillium chrysogenum and Geotrichum candidum. The pH and the total titratable acidity (TTA) varied significantly during fermentation. Carbohydrate contents significantly increased in all the fermented extrudated samples. The moisture content of the unfermented extruded samples decreased $(p<0.05)$ significantly when compared to the raw blends. Crude fibre and fat contents varied in all samples.
\end{abstract}

(Received: 13:08:2015 ; Accepted: 23:12:2015)

Key words: Fermentation, extrusion, corn-groundnut flour blend, proximate.

Correspondence: sheunheen@yahoo.co.uk

\section{Introduction}

Malnutrition is wide spread in the world today. In Africa, dietary deficiencies in terms of both qualities and quantities of food are still among the most pressing problems due to poor standard of living and low per capital income (Wooife, 1993). As a result of the relative scarcity and high cost of animal protein in developing countries especially Nigeria, the need to control and make use of cheap and acceptable forms of protein becomes absolutely necessary. Food processing techniques such as extrusion combined with fermentation would provide altemative for improving the nutritional quality of food.

In developing countries such as Nigeria, protein malnutrition persists as a principal health problem among children below the age of five (UNICEF, 1996). Therefore the need to look for inexpensive sources of protein food of good quality cannot be over emphasized. Protein calorie source of vegetable origin have been proposed as a solution to this problem (Abioye et al., 2011).

Table 1: Level combinations of com and groundnut flour blends.

\begin{tabular}{ll}
\hline Corn $(\mathrm{g})$ & Groundnut $(\mathrm{g})$ \\
\hline 100 & 0 \\
90 & 10 \\
80 & 20 \\
70 & 30 \\
60 & 40 \\
50 & 50 \\
\hline
\end{tabular}

Food crops have occupied an important place in human nutrition as they remain the major source of calories and protein for the world population particularly in the developing countries. Cereals are staples food worldwide which can be used to produce nutritious food by fortification with lysine or pulse protein. Blend flour composed of corn and groundnut can give 
a product which has high energy, protein and biological value. About 80 percent of the proteins consumed by humans in the developing countries are supplied by plants (FAO, 1988).

Fermentation has also been identified to significantly improve the nutritional value (protein quality) of corn based foods and as well as reduce their antinutritional factors (Mbugua,1998). Fermented food is any animal or plant tissue subjected to the action of microorganisms and or enzymes to give a desirable biochemical changes and significant modification of food quality (Campell-Platt, 1994). Extrusion cooking of cereals is a very important process in food industry. Extrusion cooking is one of the most efficient and versatile food processing technologies that can be used to produce pre-cooked and dehydrated food products such as snacks food, baby foods, breakfast cereals, noodles, pastas and cereals based blends. Cereals in tum are the customary, traditional snacks ingredient due to their high starch content (Perez-Navarret et al.,2006). Extrusion is used to produce nutritionally balanced food, like weaning foods, dietetic foods, and meat replacers (Plahar et al., 2003). Extrusion technology has created a huge impact in the food industries towards shaping and deriving ready to eat products (Fellows, 2009). The use of extrusion in food processing has increased its popularity due to its versatility, cost-effectiveness, environmental friendliness and better product output (Guy, 2001a). The bioavailability of nutrients during the processing of foods is always considered important when obtaining a nutritional snack product. The advantages of extrusion cooking with respect to the nutritional content of the final product are the inactivation of antinutrients, destruction of aflatoxins and increasing the digestibility of fiber (Singh et al., 2007). Flour blend of com and groundnut can give a product with high energy, protein and biological value through extrusion and fermentation. The objective of this study is to determine the influence of extrusion and fermentation on the proximate composition of com-groundnut flour blends.

\section{Materials and Methods}

The corn (Zea may averta) and groundnut (Arachis hypogeae L.) used for the research study were both obtained from Oba's market Akure in Ondo State, Nigeria.

Production and fermentation of corngroundnut blends and extrudate: The dried corn grains were sorted by hand to remove store dirt and foreign materials. The cleaned grains were milled to fine flour in the attrition mill and then sieved to fineness. The groundnut seeds were first cleaned to remove the coat and then milled to form a paste. The groundnut paste was then defatted with $\mathrm{n}$ - hexane in cold extraction. The recovered flour was air dried and clumps broken to fines. The flour samples from com and groundnut were mixed at six level combinations as shown in Table 1. The flour blends were hydrated and preconditioned by adding appropriate amount of water and mixed in a wide bowl to ensure even distribution and processed in a laboratory single screw extruder (Hobart Corporation Germany) at a screw speed of $80 \mathrm{rpm}$ and through a die nozzle diameter of $5 \mathrm{~mm}$ at $110^{\circ} \mathrm{C}$. The extrudates obtained were allowed to cool and dry before fermentation. A $100 \mathrm{~g}$ portion of each extrudate was weighed and $50 \mathrm{ml}$ of water was added. The samples were allowed to ferment at $30 \pm 2^{\circ} \mathrm{C}$ for $72 \mathrm{~h}$. The fermented samples were oven dried at $500^{\circ} \mathrm{C}$ for $24 \mathrm{~h}$

Microbiological analyses of extrudates: Microbial population of the total bacterial and fungi were determined using nutrient agar (NA) and Potato dextrose agar (PDA) respectively; organisms were enumerated by using appropriate serial dilution and pour plate techniques. The bacterial cultures were incubated in an inverted position at $37 \pm 2^{\circ} \mathrm{C}$ for $24 \mathrm{~h}$ while the fungi plates were incubated in an inverted position at $25 \pm 2^{\circ} \mathrm{C}$ for $72 \mathrm{~h}$ ( 3 days). The organisms were characterized based on biochemical and morphological observations and tests (Cowan and Steel, 1990).

Physicochemical changes

Determination of $\mathrm{pH}$ : The $\mathrm{pH}$ of all the fermenting samples (extrudates) was determined at twenty-four (24) hour intervals with a digital $\mathrm{pH}$ meter (Mettler- Toledo instrument).

Determination of total titratable acidity (TTA): The total titratable acidity of the fermenting extrudates was determined every twenty-four hour as described by AOAC (1990). Two (2) grams of the sample was weighed, 
$20 \mathrm{ml}$ of distilled water was added and then filtered. $10 \mathrm{ml}$ of the filtrate was measured and few drops of phenolphthalein indicator added. This was titrated with $0.1 \mathrm{~m}$ sodium hydroxide $(\mathrm{NAOH})$ solution and the titre values in milliliter were added from the burette. The acidity was calculated as follows: TTA $=$ Titre Value $x$ Volume of Sample $\times$ 9mg/100

Proximate analysis: Moisture content was determined by using the oven drying method which is based on weight loss and expressed as \% moisture content (A.O.A.C, 2006). Crude protein was determined from the total nitrogen (TN) determined by the microKjeldahl method by multiplying the total nitrogen by a factor of 6.25 . Crude fat was determined by using the Soxhlet extraction method using petroleum ether as the solvent (AOAC, 2006). Ash was measured by buming the sample at $550^{\circ} \mathrm{C}$ to constant weight. Carbohydrate was determined by difference.

Statistical analysis: The data were statistically analyzed using one way (ANOVA) (Steel and Torri, 1980). Duncan's multiple range tests were used to compare means and significance was accepted at $p<0.05$.

\section{Results}

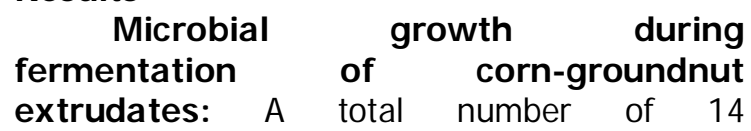
microorganisms isolated are during the fermentation of corn-groundnut extrudates. These comprise of eight (8) bacteria, five (5) moulds and one (1) yeast. They include Bacillus subtilis, Bacillus licheniformis, Leuconostoc mesenteroides, Klebsiella aerogenes, Staphylococcus aureus, Lactobacillus plantarum, Lactobacillus brevis, Micrococcus luteus, Rhizopus nigricans, Aspergillus niger, Aspergillus saprophyticus, Saccharomyces cerevisiae, Penicillium chrysogenum and Geotrichum candidum.

Changes in $\mathrm{pH}$ during the fermentation of corn-groundnut extrudates: The $\mathrm{pH}$ variation during the fermentation of corn-groundnut extrudates are shown in Figure 1. The figure showed progressive decrease in $\mathrm{pH}$ of the extrudates with changes in fermentation time. Extrudate $\mathrm{E}$ had the highest $\mathrm{pH}$ value of 6.45 at 24 hours of fermentation while the lowest $\mathrm{pH}$ was recorded in extrudate $B$ with a value of 6.25. Extrudate $B$ later recorded the highest $\mathrm{pH}$ of 5.20 and lowest $\mathrm{pH}$ value was recorded in extrudate $\mathrm{F}$ with 3.41 at 48 hours. The $\mathrm{pH}$ decreased slightly at 72 hours with the highest $\mathrm{pH}$ value of 4.61 in extrudate $\mathrm{C}$ and lowest $\mathrm{pH}$ value in extrudate $\mathrm{D}$. This was significantly different $(p>0.05)$ from the $\mathrm{pH}$ value recorded in extrudates $\mathrm{E}$ and $\mathrm{B}$.

Changes in total titratable acidity (TTA) during the fermentation of corn-groundnut extrudates: Variations in titratable acidity (TTA) during fermentation of com-groundnut extrudates are represented in Figure 2 . The TTA was highest in extrudate C ( $80 \%$ corn flour and $20 \%$ groundnut) with value of 0.71 , and was different significantly $(p>0.05)$ from the value recorded in extrudate $\mathrm{F}(50 \%$ corn flour and $50 \%$ groundnut) with a value of 0.31 at 24 hours of fermentation. The highest TTA was also recorded in extrudate C (80\% corn flour and $20 \%$ groundnut) with a value of 0.96 and significantly different $(p>0.05)$ from extrudate $D$ (70\% com flour and $30 \%$ groundnut) with the least value of 0.22 at 48 hours. The highest TTA was however recorded in extrudate A $(100 \%$ corn flour) with 0.81 while the lowest TTA was recorded in extrudate C $(80 \%$ corn flour and $20 \%$ groundnut) with 0.12 after 72 hours. 


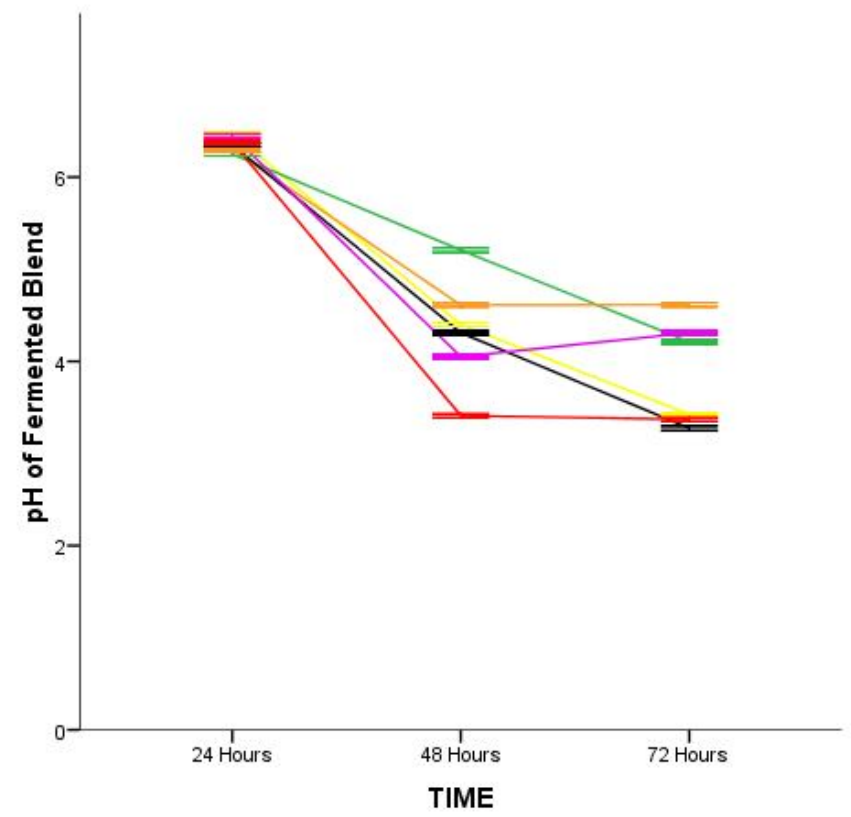

\section{COMBINATION}

A
I B
I C
I D
I E
I F

Error Bars: +/- 2 SD

Figure 1. $\mathrm{pH}$ variations during fermentation of corn-groundnut extrudates. $A=100 \mathrm{~g}$ com flour samples; $\mathrm{B}=90$ and $10 \mathrm{~g}$ corn-groundnut blend sample; $\mathrm{C}=80$ and $20 \mathrm{~g}$ corn- groundnut blend sample; $\mathrm{D}=70$ and $30 \mathrm{~g}$ corn-groundnut blend sample; $\mathrm{E}=60$ and $40 \mathrm{~g}$ corn-groundnut blend sample; $\mathrm{F}=50$ and $50 \mathrm{~g}$ com-groundnut blend sample.

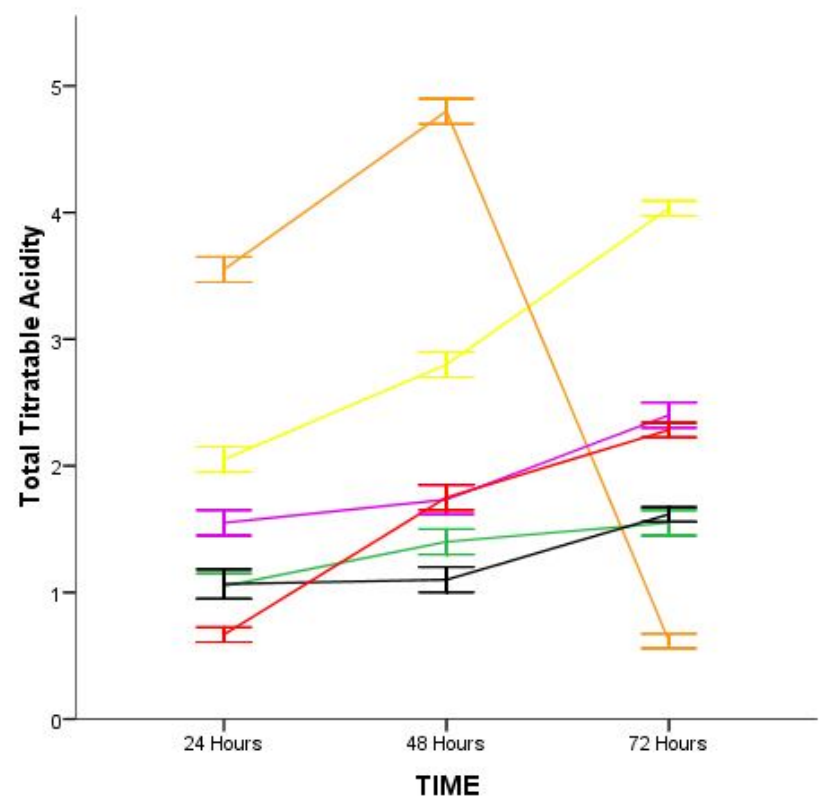

COMBINATION

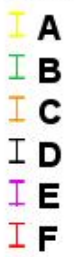

Error Bars: +/- 2 SD

Figure 2. Total Titratable Acidity (TTA) variation during fermentation of corn-groundnut 
extrudates. $A=100 \mathrm{~g}$ corn flour samples; $\mathrm{B}=90$ and $10 \mathrm{~g}$ com-groundnut blend sample; $\mathrm{C}=80$ and $20 \mathrm{~g}$ com-groundnut blend sample; $\mathrm{D}=70$ and $30 \mathrm{~g}$ corn-groundnut blend sample; $\mathrm{E}=60$ and $40 \mathrm{~g}$ comgroundnut blend sample; $F=50$ and $50 \mathrm{~g}$ corn-groundnut blend sample.

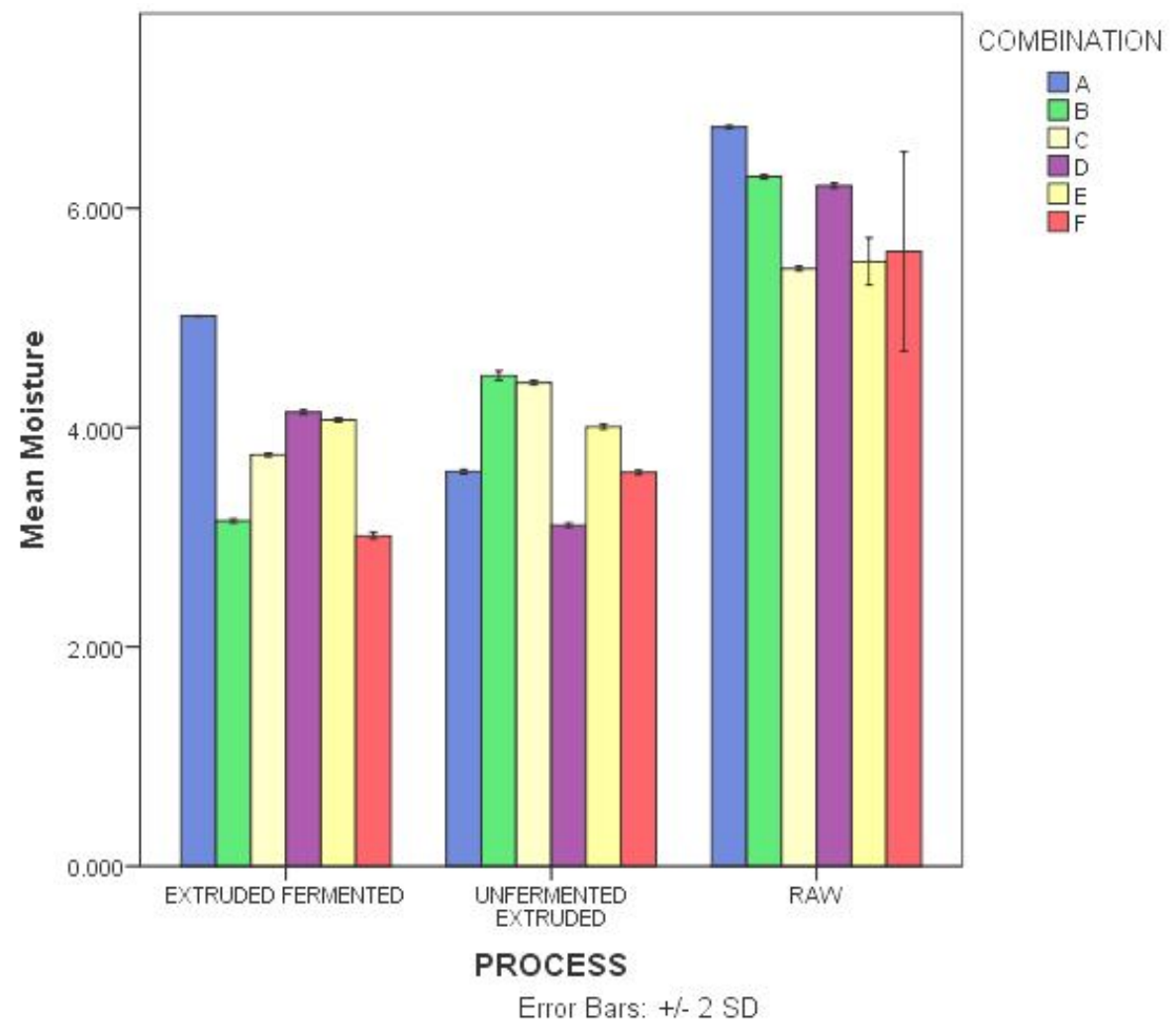

Figure 3. Moisture content of com-groundnut blends and extrudates. $A=100 \mathrm{~g}$ com flour samples; $B=$ 90 and $10 \mathrm{~g}$ com-groundnut blend sample; $\mathrm{C}=80$ and $20 \mathrm{~g}$ com-groundnut blend sample; $\mathrm{D}=70$ and 30 $\mathrm{g}$ corn-groundnut blend sample; $\mathrm{E}=60$ and $40 \mathrm{~g}$ com-groundnut blend sample; $\mathrm{F}=50$ and $50 \mathrm{~g}$ corngroundnut blend sample.

The moisture composition of corngroundnut blends and extrudates: The moisture content of corn-groundnut blends and extrudates are represented in Figure 3 . The extruded fermented sample A ( $100 \%$ corn flour) recorded the highest moisture content with the mean value of $5.01 \%$ and this was not significantly different $(p>0.05)$ from extruded unfermented sample B $(90 \%$ corn flour and $10 \%$ groundnut) with a mean value of $4.47 \%$. The least moisture content was recorded in extruded fermented sample $\mathrm{F}$ (50\% com flour and $50 \%$ groundnut) with the mean value of $3.01 \%$ and was not significantly different from the extruded unfermented sample D $(70 \%$ com flour and $30 \%$ groundnut) with the least value of $3.11 \%$. In the raw flour blend sample A
(100\% com flour) had the highest moisture content of $6.74 \%$ and the lowest moisture content was recorded in raw flour blend C $(80 \%$ corn flour and $20 \%$ groundnut) with a mean value of $5.45 \%$.

The ash composition of corn-groundnut blends and extrudates: The changes in the ash content of corn-groundnut blends and extrudates are represented in Figure 4. The extruded unfermented sample $\mathrm{F}$ (50\% com flour and $50 \%$ groundnut) had the highest ash content with the mean value of $2.21 \%$ and this was significantly different $(p<0.05)$ from the extruded fermented sample $\mathrm{F}(50 \%$ com flour and $50 \%$ groundnut) with the mean value of $1.65 \%$. The lowest ash content was recorded in extruded fermented sample D (70\% corn flour 
and $30 \%$ groundnut)with the mean value of $1.08 \%$ and was not significantly different from extruded unfermented sample A ( $100 \%$ com flour). In the raw flour blend sample $\mathrm{E}(60 \%$ corn flour and $40 \%$ groundnut) had the highest ash content content of $2.21 \%$ and the lowest ash content was recorded in sample A ( $100 \%$ corn flour) with the mean value of $1.41 \%$.

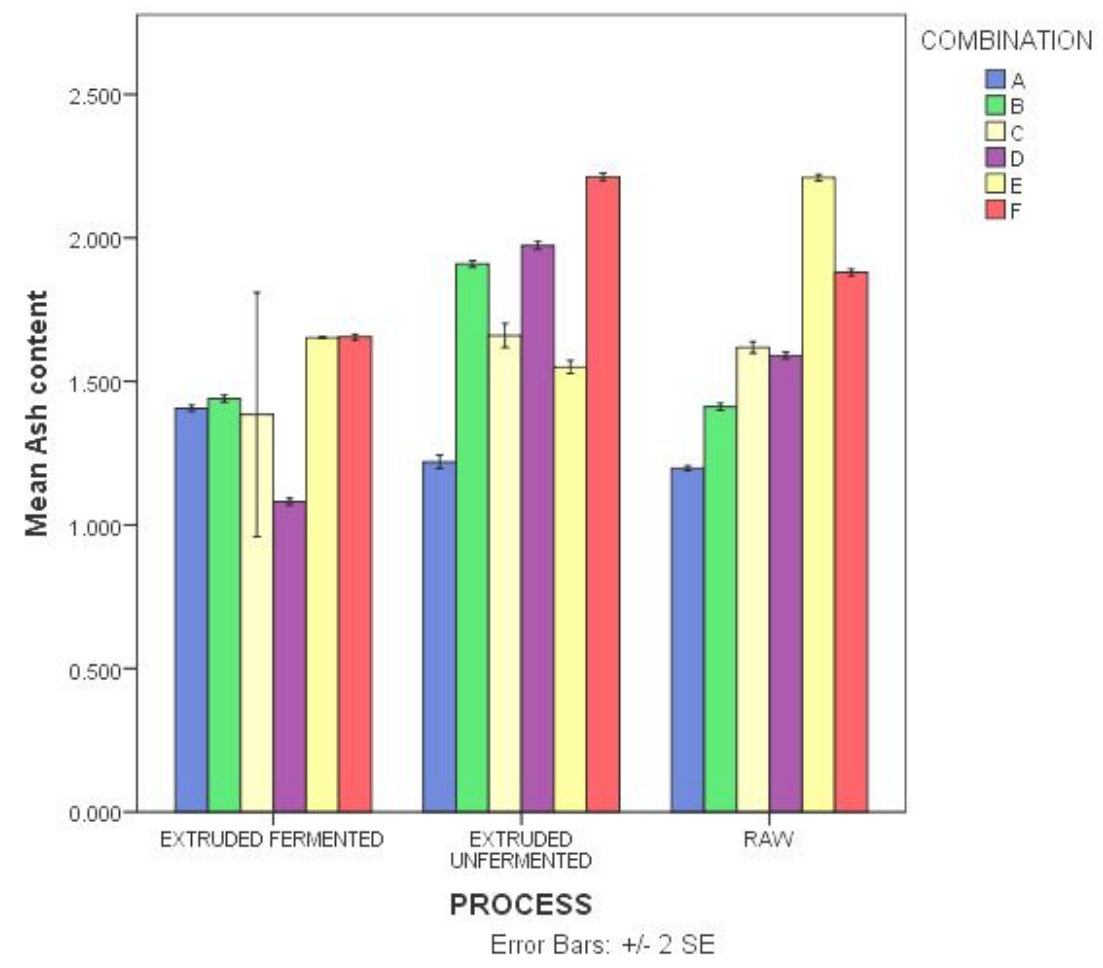

Figure 4. Ash content of corn-groundnut blends and extrudates. $A=100 \mathrm{~g}$ com flour samples; $B=90$ and $10 \mathrm{~g}$ corn-groundnut blend sample; $\mathrm{C}=80$ and $20 \mathrm{~g}$ corn-groundnut blend sample; $\mathrm{D}=70$ and $30 \mathrm{~g}$ corngroundnut blend sample; $\mathrm{E}=60$ and $40 \mathrm{~g}$ corn-groundnut blend sample; $\mathrm{F}=50$ and $50 \mathrm{~g}$ com-groundnut blend sample.

The crude fat composition of corngroundnut blends and extrudates: The crude fat content of corn-groundnut blends and extrudates are shown in Figure 5. The extruded unfermented sample E $(60 \%$ com flour and $40 \%$ groundnut) had the highest fat content with a mean value of $26.63 \%$ and was not significantly different $(p<0.05)$ from extruded fermented sample E (60\% corn flour and $40 \%$ groundnut) with a mean value of $23.49 \%$. The lowest fat content was recorded in extruded fermented sample A ( $100 \%$ com flour) with a mean value of $6.52 \%$ but this was significantly different $(p<0.05)$ from extruded unfermented sample A ( $100 \%$ corn flour) with the mean value of $8.41 \%$. The raw flour blend recorded the highest fat content in sample D $(70 \%$ corn flour and $30 \%$ groundnut) with a mean value of $22.15 \%$ and lowest fat content was recorded in raw flour blend $A(100 \%$ corn flour $)$ with the mean value of $6.03 \%$.

The crude fibre composition of corngroundnut blends and extrudates: The crude fibre content of the corn-groundnut blends and extrudates are shown in Figure 6 . The result showed that the extruded unfermented sample $\mathrm{A}(100 \%$ com flour $)$ with the mean value of $1.01 \%$ and was significantly different $(p>0.05)$ from extruded fermented sample $\mathrm{F}$ ( $50 \%$ corn flour and $50 \%$ groundnut) with the mean value of $0.81 \%$. The lowest value was recorded in extruded unfermented sample $\mathrm{F}$ (50\% com flour 
and $50 \%$ groundnut) with a mean value of $0.70 \%$ and extruded fermented sample A ( $100 \%$ com flour) with a mean value of $0.70 \%$. In the raw flour blend the highest crude fibre content was in the sample D $(70 \%$ com and $30 \%$ groundnut) with a mean value of $3.91 \%$ and the lowest in sample A (100\% corn flour) with a mean value of $1.84 \%$.

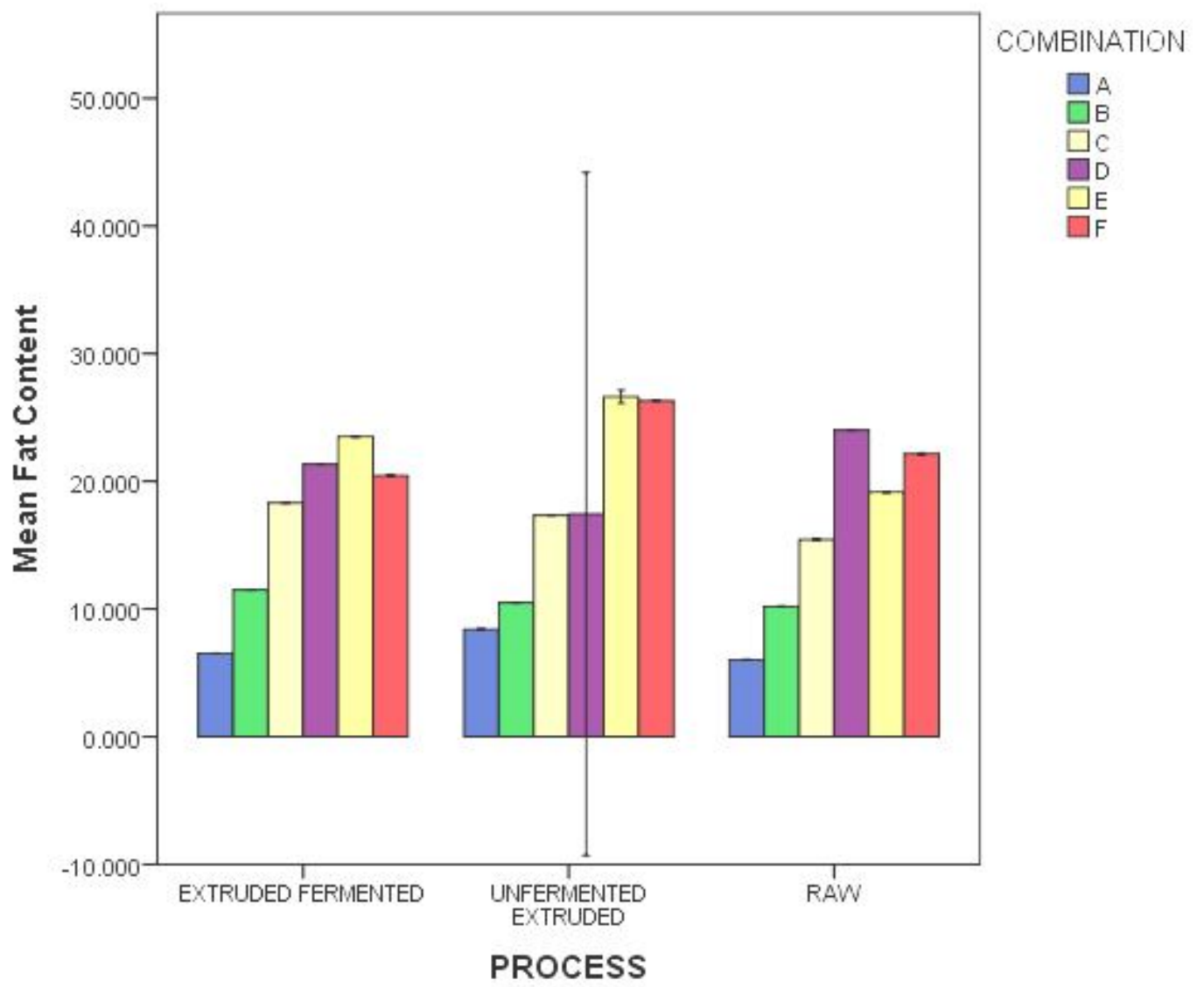

Error Bars: +/- 2 SD

Figure 5. Crude fat content of com-groundnut blends and extrudates. $A=100 \mathrm{~g}$ corn flour samples; $B=$ 90 and $10 \mathrm{~g}$ com-groundnut blend sample; $\mathrm{C}=80$ and $20 \mathrm{~g}$ com-groundnut blend sample; $\mathrm{D}=70$ and 30 $\mathrm{g}$ corn-groundnut blend sample; $\mathrm{E}=60$ and $40 \mathrm{~g}$ com-groundnut blend sample; $\mathrm{F}=50$ and $50 \mathrm{~g}$ corngroundnut blend sample. 


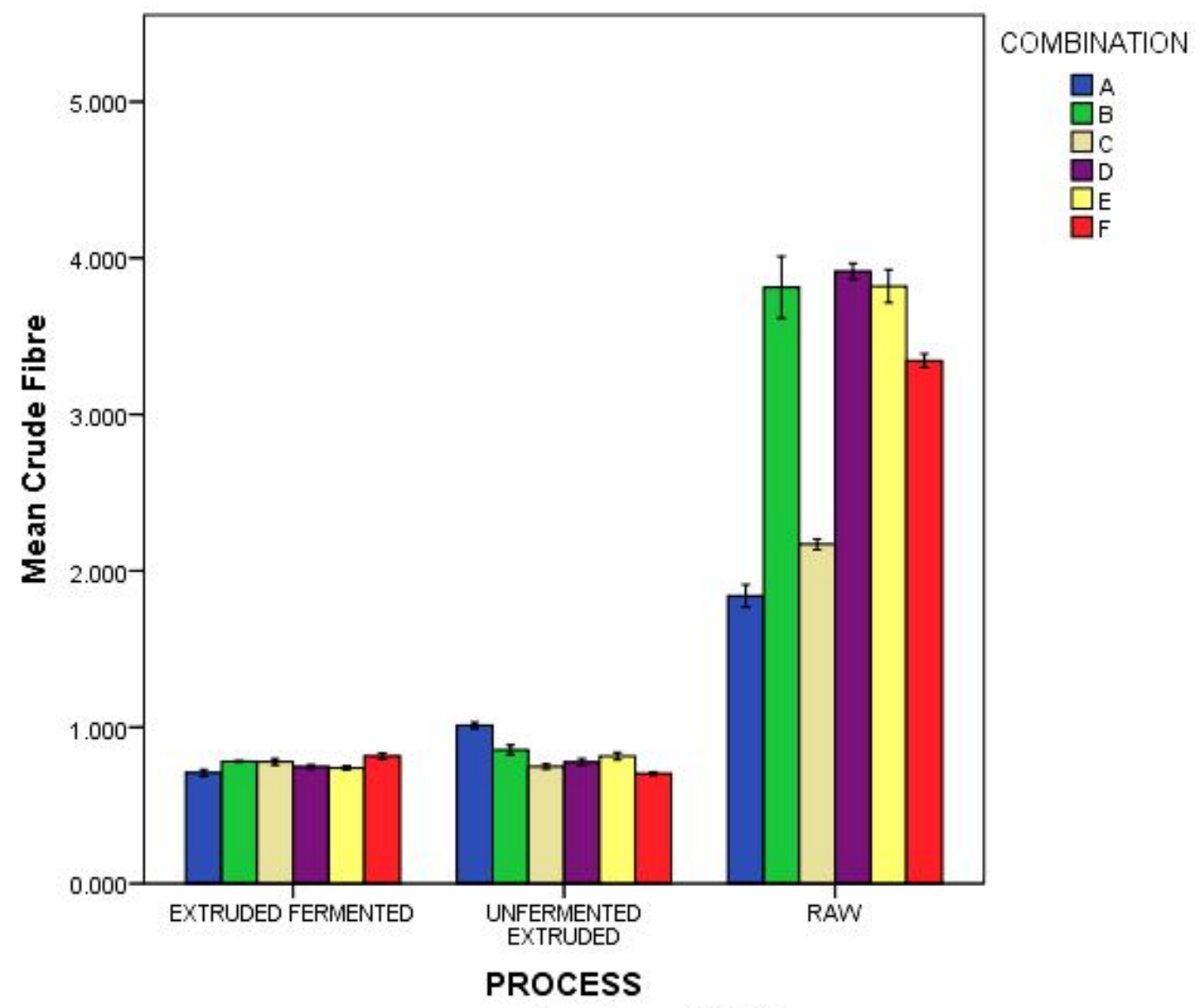

Error Bars: +/- $2 \mathrm{SD}$

Figure 6. Crude fat content of corn-groundnut blends and extrudates. $A=100 \mathrm{~g}$ corn flour samples; $B=$ 90 and $10 \mathrm{~g}$ com-groundnut blend sample; $\mathrm{C}=80$ and $20 \mathrm{~g}$ com-groundnut blend sample; $\mathrm{D}=70$ and 30 $\mathrm{g}$ corn-groundnut blend sample; $\mathrm{E}=60$ and $40 \mathrm{~g}$ com-groundnut blend sample; $\mathrm{F}=50$ and $50 \mathrm{~g}$ corngroundnut blend sample.

The crude protein composition of corngroundnut blends and extrudates: The crude protein content of the corn-groundnut blends and extrudates are shown in Figure 7. The protein content was highest in extruded unfermented sample B (90\% corn flour and $10 \%$ groundnut) with a mean value of $24.91 \%$ and was not significantly different $(p<0.05)$ from extruded fermented sample $\mathrm{F}$ ( $50 \%$ com flour and $50 \%$ groundnut) with a mean value of $24.84 \%$. The lowest protein content was recorded in extruded fermented sample A ( $100 \%$ corn flour) with mean value of $12.30 \%$ and was significantly different ( $p>0.05$ ) from the extruded unfermented sample A $(100 \%$ com flour) with the mean value of $15.05 \%$. In the raw flour blend sample $\mathrm{F}(50 \%$ corn flour and $50 \%$ groundnut)recorded the highest protein content with a mean value of $21.90 \%$ and the lowest protein content was recorded in sample $A$ ( $100 \%$ com flour) with a mean value of $12.36 \%$.

The carbohydrate composition of corngroundnut blends and extrudates: The carbohydrate content of the blends and extrudates are shown in Figure 8. The carbohydrate content was highest in extruded fermented sample A ( $100 \%$ corn flour) with a mean value of $71.64 \%$ and this was significantly different $(p<0.05)$ from the extruded unfermented sample A ( $100 \%$ corn flour) with the mean value of $69.52 \%$. The lowest 
carbohydrate content was recorded in extruded fermented sample E (60\% corn flour and $40 \%$ groundnut) with the mean value of $49.22 \%$ and extruded unfermented sample $\mathrm{F}$ ( $50 \%$ com flour and $50 \%$ groundnut) with a mean value of $42.87 \%$. In the raw flour blend sample $A$ had the highest carbohydrate content with a mean value of $68.52 \%$ and the lowest carbohydrate content was recorded in raw flour blend E $(60 \%$ com flour and $40 \%$ groundnut) with the mean value of $40.31 \%$.

\section{Discussion}

The microbiological changes observed during the fermentation was as a result of

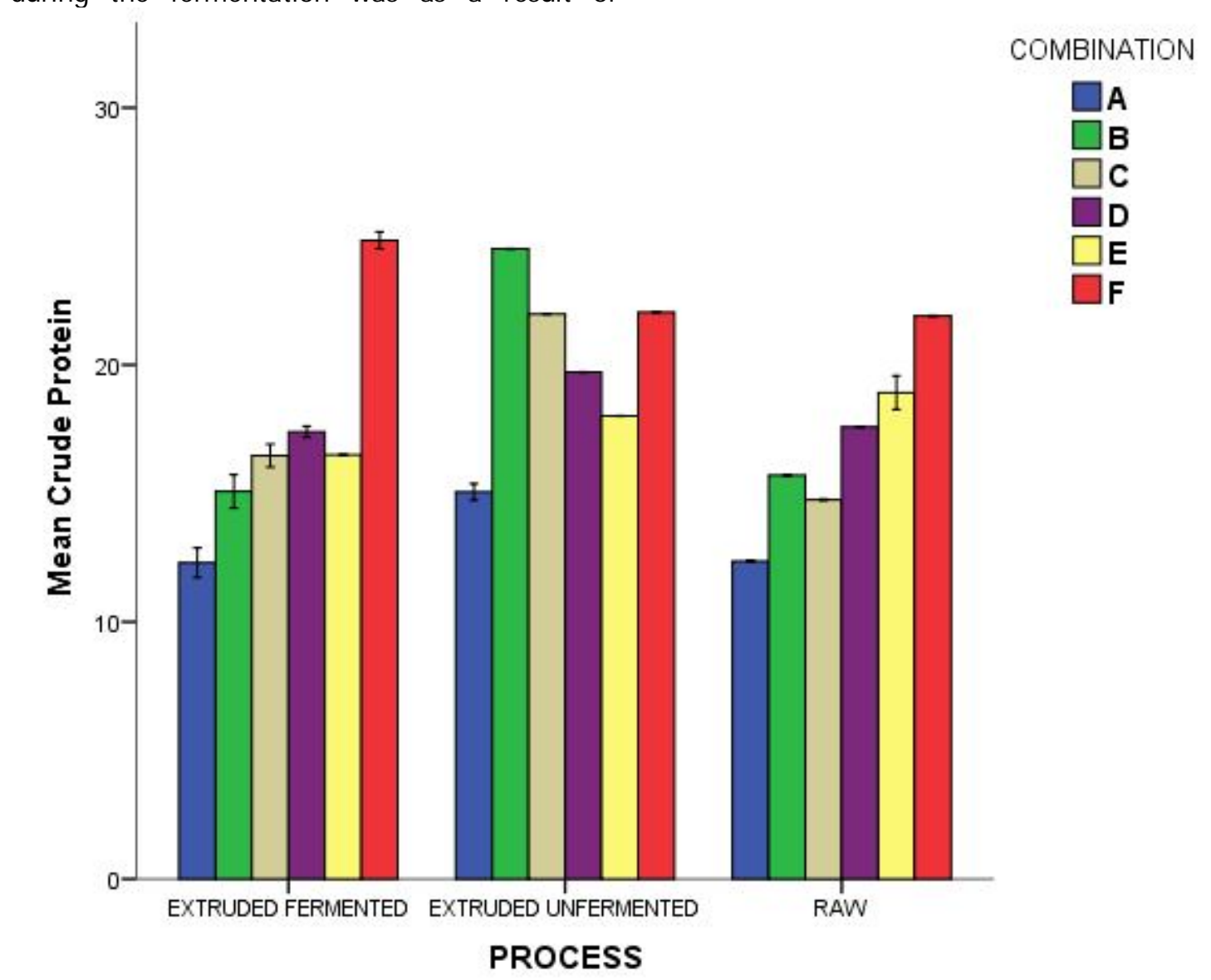

Error Bars: +/- $2 \mathrm{SE}$ increase in total bacteria count. The results showed that a diverse group of microorganisms were present during the fermentation process. The type of fermentation carried out in this study was natural fermentation. According Cavalieri et al. (2003) natural fermentation is the conversion of carbohydrates to alcohol and carbondioxide or organic acids using fungi, bacteria or a combination there of under anaerobic conditions. Bacillus subtilis and Bacillus licheniformis were isolated from the extrudates that were fermented. These two microorganisms amongst others were also identified by Odunfa (1981), Barber et al. (1988)

Figure 7. Crude protein content of corn-groundnut blends and extrudates. $A=100 \mathrm{~g}$ corn flour samples; $\mathrm{B}=90$ and $10 \mathrm{~g}$ com-groundnut blend sample; $\mathrm{C}=80$ and $20 \mathrm{~g}$ corn-groundnut blend sample; $\mathrm{D}=70$ and $30 \mathrm{~g}$ corn-groundnut blend sample; $\mathrm{E}=60$ and $40 \mathrm{~g}$ com-groundnut blend sample; $\mathrm{F}=50$ and $50 \mathrm{~g}$ corngroundnut blend sample. 


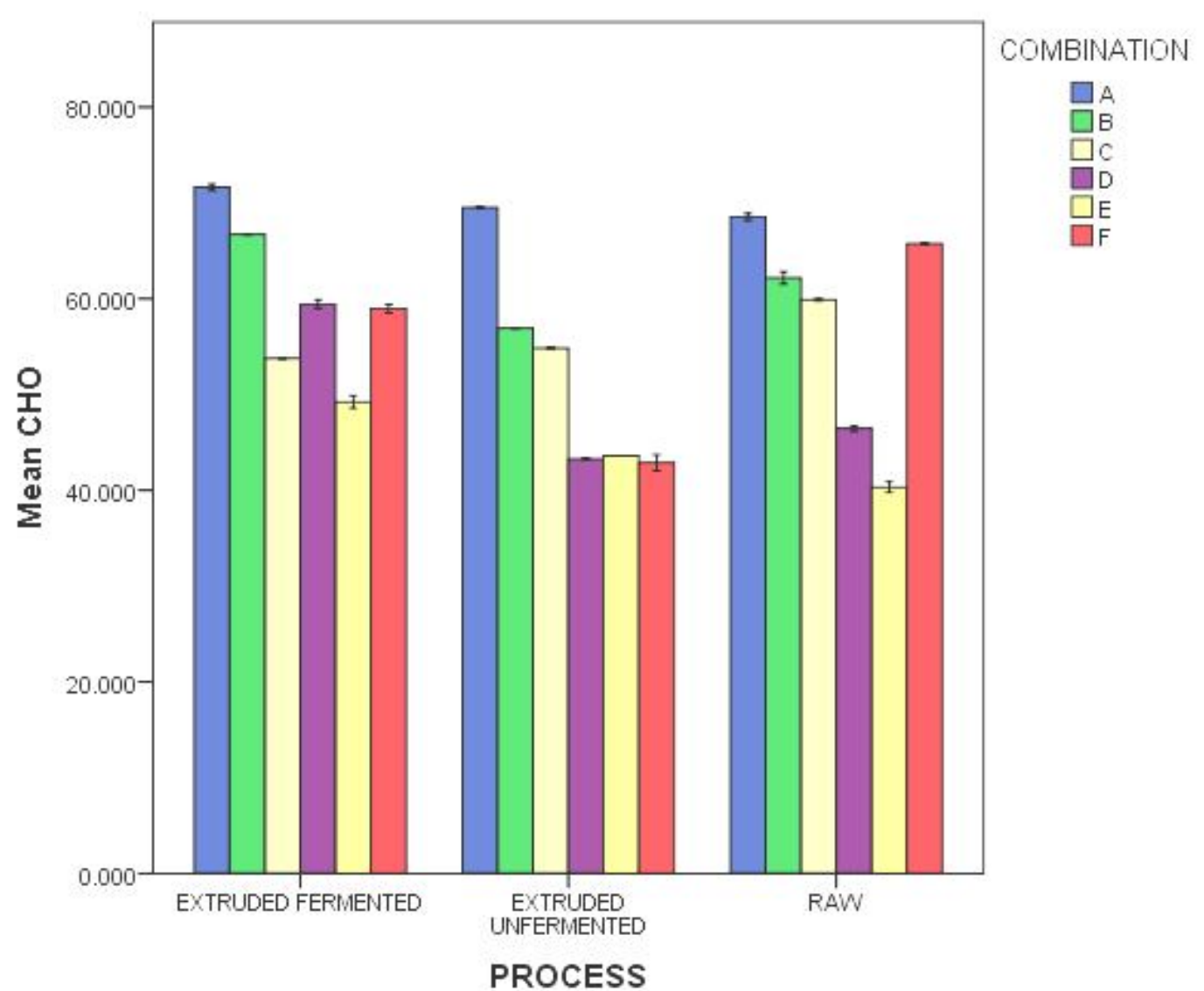

Error Bars: +/- 2 SE

Figure 8. Carbohydrate content of corn-groundnut blends and extrudates. $A=100 \mathrm{~g}$ corn flour samples; $\mathrm{B}=90$ and $10 \mathrm{~g}$ com-groundnut blend sample; $\mathrm{C}=80$ and $20 \mathrm{~g}$ corn-groundnut blend sample; $\mathrm{D}=70$ and $30 \mathrm{~g}$ corn-groundnut blend sample; $\mathrm{E}=60$ and $40 \mathrm{~g}$ com-groundnut blend sample; $\mathrm{F}=50$ and $50 \mathrm{~g}$ corngroundnut blend sample.

and Ogbadu and Okagbue (1988) in their studies. The involvement of Staphylococcus aureus may be attributed to handling and normal contaminants and this microorganism played no role in the fermentation process while the presence of Rhizopus nigricans could be due to microbial flora associated with groundnut.

The bacteria count later decreased at 72 hours of the fermentation. The gradual decrease in microbial load in the extrudates might be as a result of decrease in $\mathrm{pH}$ and increase in total titratable acidity (TTA). The increase in the acidity is important to avoid the proliferation of undesirable organisms. The decrease in $\mathrm{pH}$ might be as a result of the activities of microorganisms on the fermentable substrate which lead to the hydrolysis of complex organic compounds of the substrate thereby producing acid and ethanol. The acid produced lead to decrease in $\mathrm{pH}$ and increase in total titratable acidity. The predominant microflora in the corngroundnut flour blends were Lactobacillus species, Leuconostoc species and some Aspergillus species.

The carbohydrate content of the extrudate with $100 \%$ corn flour was the highest among all the extrudates; while the extrudate that contained equal amount of corn and groundnut in the ratio 50:50 had the lowest carbohydrate content. This is inevitable because corn is majorly a carbohydrate based cereal. The carbohydrate content of the sample with equal amount of corn and groundnut was actually the lowest because groundnut is a protein based 
food. The increase in carbohydrate content was most significant in the fermented extruded samples.

The moisture content of all the unfermented extruded samples decreased significantly $(p<0.05)$ when compared to the raw blends. This could be because of the type of cooking involved. Extrusion cooking is a versatile food processing technologies that can be used to produce pre-cooked and dehydrated foods (Onyango et al., 2004b). The reduced moisture content of the extrudates reduce the cost of post extrusion drying and guarantees an improved shelflife of the products (Berk, 1992).

Fat content are one of the major components of food that provides energy and essential lipids. Fat increased with groundnut level supplementation in addition to extrusion cooking. The increase in fat content of the unfermented extrudates could be due to melting of the oils due to heat treatment applied during extrusion (Nwanbueze, 2006). Lipid constituent is a major determinant of overall physical characteristics, such as aroma, texture, the month-feel and appearance.

Ash is an inorganic residue remaining after the removal of water and organic matter which provides a measure of total amount of minerals in the food component. Ash content of the unfermented extrudates were significantly low. The ash of a biological material is an analytical term, the inorganic residue that remains after the organic matter has been burnt away. The significantly $(p<0.05)$ lower ash content values recorded in fermented extrudates as compared with unfermented extrudates could be as a result of leaching of water soluble minerals of the extrudates during fermentation process and this loss of minerals could have served as the mineral source for the fermenting microorganisms(Abu, 2005).

The extrudates with the highest proportion of groundnut had the highest protein content. The result from this study confirmed the observation that groundnut is rich in protein content. As the groundnut proportions were increased the protein content of the sample increased significantly $(p>0.05)$. The decrease in protein content in some of the unfermented extrudates compared with the fermented extrudates could as well be attributed to interaction of amino acid in maillard reactions.
This could also be as a result of excessive heating during extrusion cooking.

Crude fibre is the portion of the total carbohydrate of a food that is resistant to the acid and alkali treatment. The name is derived from the fact that it has a naturally fibrous structure. The values of crude fibre in unfermented extrudates was low compared to the raw blends. Fermentation further caused reduction in the crude fibre content of the extruded fermented samples. This could be as a result of the activities of microorganisms involved in the fermentation process. The presence of cellulose enzymes could have aided the breakdown of the crude fibre.

\section{Conclusion}

Extrusion cooking and fermentation have some significant effect on the nutritional value of food most especially the proximate composition. The physical and functional quality of food could be greatly enhanced through extrusion. Extrusion being a high temperature short-time process can be employed in the production of better quality food materials. The extrudates have good potential as a cheap source of ready to eat diet rich in nutrient, which could be utilized to improve food security against malnutrition.

\section{References}

A. O. A. C. (1990). Hydrocyanic acid in beans, alkaline titration method. In: Official Methods of Analysis; 15th Ed, AOAC, Inc, Arlington, Va, USA, 1213

A.O.A.C. (2005). Official method of Analysis of AOAC International $18^{\text {th }}$ ed. Maryland, USA.

Abioye, V. F., Ade-Omowaye, B. I. O., Babarinde, G. O. and Adesigbin, M. K. (2011).Chemical, physico-chemical and sensory properties of soy-plantain flour. In African J ournal of Food Science; 5 (4): 176 - 180.

Abu, E.A., Ado, S.A. and James, D.B. (2005). Raw starch degrading amylase production by mixed culture of Aspergillus niger and Saccharomyces cerevisiae on Sorghum pomace. on Sorghum pomace. Biotechnology; 4: 785790. 
Barber, L.B., Thurman, E.M., Schroeder, M.P. and LeBlanc, D.R. (1988) Long-term fate of organic micropollutants in sewage-contaminated groundwater. Environmental Science of Technology; 22 (2) : 205-211

Berk, Z., (1992). Textured soy protein product, Chapter 7 in technology of production of Edible flours and protein products from soybeans, FAO Agricultural Services Bulletin No. 97, Food and Agriculture Organisation of the United Nations Rome,

www.fao.org/docrep/t0532e/t0532e08.htm.

Campbell-Platt, G. (1994). Fermented foods -a world perspective Food Research International; 27: 253-262.

Cavalieri, D., McGovern, P.E., Hartl, D.L., Mortimer, R. and Polsinelli, M. (2003). Evidence for Saccharomyces cerevisiae fermentation in ancient wine. Joumal of Molecular Evolution; 57(1): 229-232.

Cowan, S.T., Steel, K.J. (1990). Bergy's manual of determinative microorganism $4^{\text {th }} \mathrm{Ed}$. Published by Cambridge university press; pp 58.

FAO (1998). Animal Feeding and Food Safety. Report of an FAO Expert Consultation. Food and Agriculture Organization of the United Nations.

Fellows, P. (2009). Food Processing Technology Principles and Practice. Fermented Ghanaian maize dough. J ournal of Applied Bacteriology; 7: 203-210.

Guy, R. (2001a). Extrusion cooking technologies and applications, Woodhead publishing Ltd, Cambridge, UK: 1-2.

Mbugua, S. K. (1998). The nutritional and fermentation characteristics of $\mathrm{Uji}$ produced from dry milled flour and whole wet milled maize. Chemical Microbiology Technology Ledensmittel; 10: 154-161.

Nwabueze T.U. (2007) Nitrogen solubility index and amino acid profile of extruded African bread fruit ( $T$. africana) blends. Nigeria Food J ournal; 25(1): 23-35.
Odunfa, S.A. (1981) .African fermented foods, In: Microbiology of fermented Foods, Vol.2, (Ed.) BJ B Wood Chapter 6, pp. 155-191, Elsevier Applied Science Publisher, London and New York.

Ogbadu, L.J. and Okagbue, R.N. (1988). Bacterial fermentation of soya bean for dadawa production. Joumal of Applied Bacteriology ;65(5): 353-356.

Onyango, C., Noetzold, H., Bley, T. and Henle, T. (2004). Proximate composition and digestibility of fermented and extruded uji from maize-finger millet blend. Lebensmittel Wissenchaft and Technology; 37: 827-832.

Perez-Navarrete, C., Gonzalez, R., ChelGuerrero, L. and Betancur-Ancona, D. (2006). Effect of extrusion on nutritional quality of maize and lima bean flours blends. Journal of Science Food and Agriculture; 86 (14): 2477-2484.

Plahar, W. A., Okezie, B.O. and Gyato, C.K. (2003). Development of a high protein weaning food by extrusion cooking using peanuts, maize andsoybeans. Plant Foods Human Nutrition; 58: 1-12.

Singh, D. A. P., Kumar, P. and Saravanakumar, V. R. ( 2007). Production performance of White Giant rabbits fed with Tridax procumbens. Indian Veterinary J ournal; 84 (11): 1212-1213

Steel, R. G and Torri, J.H. (1980) Principles and procedures of statistics. Mc Graw-Hill Book, Co., Inc., New York USA.

United Nations Children Emergency Fund. Child Nutrition, New York, USA. Published for UNICEF by Oxford University Press 1996. Use as Complementary Foods in Nigeria. Plant Foods for Human Nutrition; 55: 255-26.

Wooife, R. (1993) The Path to Strategic Alignment Information Strategy: The Executives Journal Winter pp 13-23(Reprinted from Sc index I ndications Vol 9 No 2 1992). 